\title{
Children and Childhood
}

\section{Key Web Resources for Children's librarians}

\author{
COMPLLED bY TESS PRENDERGAST AND BETSY DIAMANT-COHEN
}

$\mathrm{T}$ his list of links provides children's library practitioners with what we believe are essential web resources to help inform and inspire you as you work with children and families. Knowing about the work of other organizations can help librarians put their work into perspective as well as sharpen their understanding of how important children's library services are within diverse communities. Getting acquainted with some of the following organizations' resources will help prepare children's library practitioners to approach partnerships and new initiatives with a clear understanding of the collective goals of supporting child development across contexts.

\section{Colorín Colorado}

www.colorincolorado.org

This bilingual site for families and educators (including a section specifically for librarians) abounds with suggestions for teaching English-language literacy skills to English Language Learners. Designed with Spanish speakers in mind, the majority of the activities are geared for children from pre-K-3. A section for librarians has links to articles, videos, booklists, and information about the Pura Belpré Award. Tips for parents and caregivers, written in plain language, are available in both English and Spanish. Produced by Reading Rockets, a public broadcasting station, there are many free downloads and a wonderful glossary of educational terms and acronyms.

\section{Early Childhood Investigations}

www.earlychildhoodwebinars.com

This website offers free webinars on a variety of topics throughout the year for those who work with children. Its goal is to "spark discussion in the preschool community, and engage and motivate directors and teachers." Designed mainly for early childhood educators, the content of these seminars is widely applicable to children's services librarians. In fact, several librarians have delivered webinars here already, focusing on universally important topics in childhood such as early literacy, STEM, and digital technology. Sign up for their newsletter to hear about new free webinars and learn more about how to better meet the learning needs of the children in your communities.

\section{Earlylit.net}

http://earlylit.net

The website of Early Childhood Literacy Consultant Saroj Ghoting, Earlylit.net lists and links to a variety of useful resources for children's librarians on topics such as demographics related to early literacy, brain development and child development, language development and early literacy skills, books/reading and early literacy skills, the five practices, effect of media viewing on language development, and bilingual language and learning. Links to information about early literacy spaces in public libraries, direct links to public library websites with information about early literacy, links to Spanish-language resources, Storytime Share with early literacy tips for parents and caregivers, and a wide variety of downloadable handouts make this website user friendly and extremely valuable.

\section{Erikson Institute}

www.erikson.edu

Much more than a graduate school of child development, Erikson Institute is a treasure trove of resources for people who work with and seek to learn more about various aspects of 
childhood and the factors that impact children's development. An exploration of some of the Erikson website areas will reveal opportunities to take free and low-cost continuing education online courses and webinars as well as links to many of the research reports that the Erikson has published. Signing up for the Erikson Institute's e-newsletter means that you will get regular updates on their important work.

\section{Fred Rogers Center}

www.fredrogerscenter.org

Everything that Fred Rogers Center produces is research-based and focused on providing children with the best possible experiences. Spending time getting to know the resources available on this website will prove highly valuable to children's services librarians who are wondering about how to navigate the screen debate in their workplaces. In his lifetime, Fred Rogers committed himself to "building bridges between early learning and children's media.” The website provides a range of balanced and current research about children, television, and other digital content. The main website branches off to the "Ele" section, which is dedicated to early learning environments-easy to navigate and customizable by age, activity, and media type.

\section{The National Institute for Play}

www.nifplay.org

Although play is one of the five practices of Every Child Ready to Read and is often referred to as "the work of childhood," many children's librarians lack scholarly resources to support their inclusion of play experiences in library spaces and programs. The National Institute for Play gathers scientific knowledge on play, compiles research findings, lists research references, describes types and patterns of play in easily understandable language, connects play experiences with children's healthy development, translates the knowledge into programs and resources, and shares this information in order to "deliver the transformative power of play to all segments of society."

\section{National Scientific Council on the Developing Child (at Harvard University)}

http://developingchild.harvard.edu

Citing research in an easy-to-understand way can provide justification for the importance of library programs for young children and make great developmental tips for parents and caregivers. Free downloadable working papers explain the importance of joyful, nurturing experiences in the earliest years of life, which is what early childhood library programs are meant to be. The National Scientific Council on the Developing Child uses science to inform adults about what children need in order to live healthy and productive lives. Subscribe to their free newsletter and keep up-to-date with the most recent research.

\section{Zero to Three}

www.zerotothree.org

The mission of this organization aligns well with our own goals. As librarians, we provide services for families with infants and toddlers, including the provision of programs for babies. Zero to Three focuses on the importance of the very early years of development and stresses that what happens to young children matters. By providing a wide range of accessible research and other material, this organization is dedicated to helping others learn about babies and toddlers and how to care for the babies and care for the caregivers. $\&$.

\section{Index to Advertisers}

Bedtime Math ....................... Cover 4

Boyds Mills Press..................... Cover 2
Arne Nixon Center $\ldots \ldots \ldots \ldots \ldots \ldots \ldots \ldots \ldots \ldots \ldots$

University of Alaska Press ................. Cover 3 


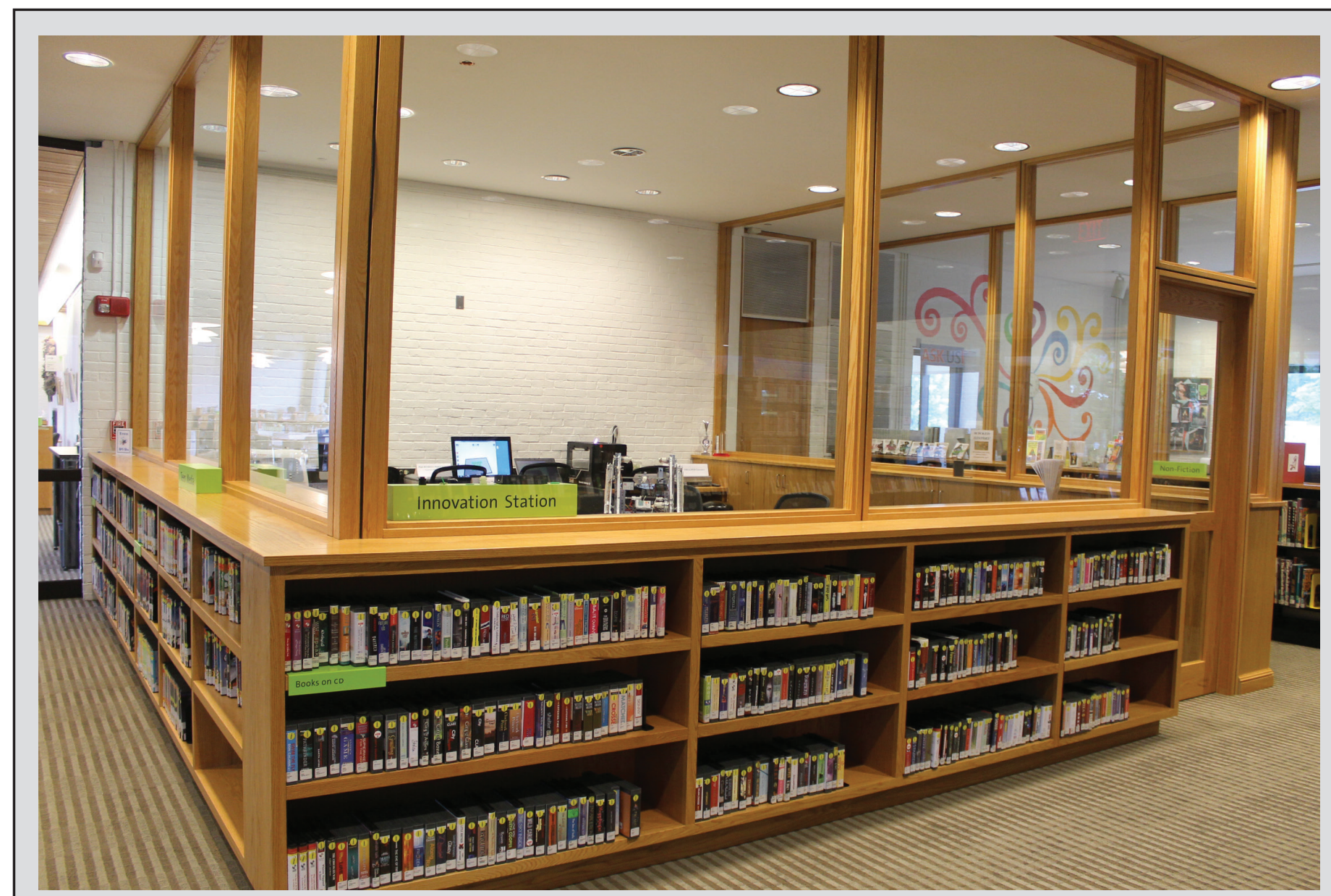

\section{Wilton Library Opens Innovation Station}

The question buzzing around Wilton, Conn., these days is "What came first . .. the library's robotics team or the new makerspace?" Both ideas had been percolating inside and outside Wilton's library community for a while and their stories intertwine. But officially, the Wilton Library robotics team, dubbed Singularity Technology, became a reality in September 2013 and Wilton Library's maker space, Innovation Station, opened to the public in June 2014.

Executive Director Elaine Tai-Lauria targeted STEAM (Science, Technology, Engineering, Arts, and Math), as well as learning new technology, as a focus-as well as making both accessible to the community. The community's techloving teens, working with the library's Teen Services department, came together to form the first ever library-supported FIRST Tech Challenge robotics team. The team was housed in the library's sub-basement, previously storage for archived newspapers and music records. Working in this less than ideal space, Singularity Technology managed to achieve great success in its rookie year, securing a coveted spot in the State Championships.

With a burgeoning robotics team needing a more tech-friendly space and a maker space topping Wilton Library's wish list, the race was on to bring Wilton its own community-friendly area to make STEAM learning accessible. Through a generous grant from the Shoff Foundation as well as a series of private donations, Wilton Library's own maker space became a reality.

"Our Singularity Technology team and Innovation Station are both new ventures for us. In the past we've certainly had rich programming and wonderful resources. Now, with Innovation Station, we are bringing the community into a new kind of educational experience-an adult crafting experience, one that offers firsthand learning with cutting edge technologies and a DIY attitude," says Tai-Lauria. "And the robotics team offers our young tinkerers a more hands-on study of the robotics that may well become the career opportunity of tomorrow."

Working within library walls, it was decided that space adjacent to the Teen Services area was the ideal spot for the maker space. The plans, drawn-up by New York-based designer Lisa Waldie, called for a near seamless design to match the library's existing finely-milled oak cabinetry and sleek glass interiors. The new 320-square foot space allows for up to twenty creators to work simultaneously and for those outside in other library spaces to see the innovations happening within. 